\title{
Liam Donaldson: Proud of smoke-free public places
}

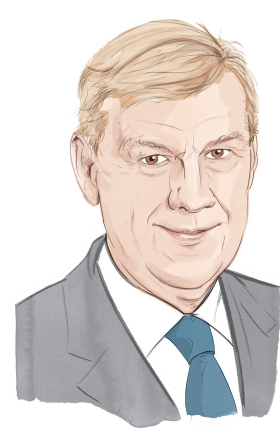

\section{What was your earliest ambition?}

Cowboys were everything. My hope was to be deputised by a passing sheriff and join his posse in pursuit of outlaws. But disappointingly few sheriffs galloped past our house in Rotherham.

\section{Who has been your biggest inspiration?}

The first chief medical officer, John Simon, who served for 21 years. His crucial influence on the public health measures introduced over that time laid the foundations for the improvements to the country's health that took place over the new century.

\section{What was the worst mistake in your career?}

Turning down the chance to apply to be NHS chief executive. Building a new service around health, quality, and safety by igniting the passion of a million loyal and dedicated staff would have been a unique leadership challenge. But I decided that my mission as chief medical officer hadn't been completed.

\section{What was your best career move?}

Becoming the country's 15th chief medical officer.

\section{Bevan or Lansley? Who has been the best and the worst health secretary in your lifetime?}

Alan Milburn was an inspired appointment and had the right vision for the NHS, and - unusually, for a politician-he understood how to implement it. Iain Macleod, minister of health in 1954, chain smoked disgracefully through a press conference that he'd been forced to convene to announce [Austin] Bradford Hill and [Richard] Doll's findings on smoking and lung cancer. The politics of tobacco were particularly murky at that time. Someone of real courage, in an era when people would tend to listen to a government's advice, could have changed attitudes and behaviour earlier and saved many more lives.

\section{Who is the person you would most like to thank, and why?}

The people in that much derided place, the House of Commons. They implemented many recommendations from my reports, for which I'm deeply grateful: introducing smoke-free public places; permitting stem cell research; establishing clinical governance; creating a national patient safety programme; establishing a comprehensive health protection service; and reforming medical regulation. But they didn't act on my final report's recommendation for a minimum price for units of alcohol. They fear being labelled as the nanny state. They need not: the public respects strong action on public health.

\section{To whom would you most like to apologise?}

Healthcare leaders around the world should not only apologise to the hundreds of thousands of patients and families who continue to be harmed by unsafe care but should show that they can re-orient their systems to learn.

\section{If you were given $£ 1 \mathrm{~m}$ what would you spend it on?}

Commissioning new statues of the great public health figures of the past whose gift to us is the longevity we have today. They should be remembered and celebrated as much as our warriors. It's a scandal that Edward Jenner's statue was removed from Trafalgar Square.

\section{Where are or were you happiest?}

After leaving home for the first time to go to university. It was 1967: everything seemed possible. A close second would be St James's Park during Kevin Keegan's period of management at Newcastle. 


\section{Biography}

Liam Donaldson was England's chief medical officer for more than a decade, from 1998 to 2010. His greatest achievement was to bring about the ban on smoking in public places despite opposition from the government of the day. He also backed a minimum price for alcohol, championed patient safety, and shepherded sensible rules on stem cell research into legislation. A lifelong supporter of Newcastle United (a condition for which there is no known cure), he marked his inauguration as chancellor of Newcastle University in 2009 by awarding an honorary degree to Alan Shearer, a club icon.

\section{What single unheralded change has made the most difference in your field in your lifetime?}

Non-smoking becoming the social norm (just about).

\section{Do you support doctor assisted suicide?}

No: that's not what medicine is for. Our best palliative care services should be available everywhere. Many elderly people feel so lonely, unwanted, and burdensome (some even to their own families) that they may too easily give up on life. We badly need a more positive vision of ageing and greater societal engagement with those in their later years.

\section{What book should every doctor read?}

Eliot Freidson's Profession of Medicine. It's a sociological analysis that brilliantly demonstrates the attributes that define a profession but also its downside-how it resists change.

\section{What poem, song, or passage of prose would you like mourners at your funeral to hear?}

The choreographer need look no further than the collected works of Bob Dylan, perhaps ending with a reading of the lyrics of "Forever Young."

\section{What is your guiltiest pleasure?}

Reading a good novel while drinking a cup of great coffee, when I should really be working.

\section{If you could be invisible for a day what would you do?}

That's not a superpower I warm to . . . but time travel, if only for a day, really would be something.

\section{What television programmes do you like?}

Most of the BBC dramas (Wolf Hall, most recently). And the major US series - such as House of Cards and Fargo - are often brilliant.

\section{What is your most treasured possession?}

Memories of people, events, special moments, and belonging to great teams are more precious to me than tangible possessions.

\section{What, if anything, are you doing to reduce your carbon footprint?}

I walk a lot, but I don't do well on the air travel front, given my global health commitments.

\section{What personal ambition do you still have?}

There's plenty still to strive for in my role as the World Health Organization patient safety envoy and as chair of the Independent Monitoring Board of the polio eradication programme. Healthcare systems around the world have many of the same problems, and it's always fulfilling to share my experience with others in trying to find solutions.

\section{Summarise your personality in three words}

Determined, insightful, fair-minded.

\section{Where does alcohol fit into your life?}

Promoting the WHO programme to introduce affordable effective alcohol hand rubs in hospitals throughout the world Hundreds of thousands of lives have been, and still could be, saved by good hand hygiene. Sounds simple, but it isn't.

\section{What is your pet hate?}

People who only ever see the negative side of things.

\section{What would be on the menu for your last} supper?

I think I'd be too busy to eat, trying to find a way out of the situation.

\section{Do you have any regrets about becoming a doctor?}

I trained in an era when the paths to career progression were very rigid. When I left surgery after passing the fellowship and was on a prestigious training programme I was described as "half crazed": no one on a successful trajectory could possibly want to leave surgery. When they heard that I was going to retrain in public health, the word went around that I had the ambition of becoming a "town clerk." I have no regrets of ending up where I did, as regional director and chief medical officer (and I still like surgeons), but making my way up from the bottom in a Cinderella specialty was difficult at times. Thank goodness for mentors such as Muir Gray.

\section{If you weren't in your present position what would you be doing instead?}

Something in the creative arts: theatre, literature, or film. After a lifetime of working within the rules and constraints of bureaucracies, that would be the contrasting alternative life. 